\section{Whither Private Higher Education in Africa?}

\section{Mahlubi Mabizela}

Mahlubi (Chief) Mabizela, PROPHE collaborating scholar, is a research specialist at South Africa's Human Sciences Research Council. Address: Private Bag X 41, Pretoria, 0001 , South Africa. E-mail: cmabizela@hsrc.ac.za.

IHE devotes a column in each issue to a contribution from PROPHE, the Program for Research on Private Higher Education, headquartered at the University at Albany. See http://www. albany.edu/ prophe.

$\mathrm{T}$ he United States International University in Kenya convened the first private higher education conference in Africa in early September 2003. The majority of approximately 90 delegates were senior personnel of private higher education institutions from about 10 African states, but participants also included representatives of supranational organizations, governments, diplomatic missions, academics, and researchers. They deliberated on the theme: "Meeting the Challenges of Higher Education in Africa: The Role of Private Universities," and they shared experiences and ways of setting up networks. This article highlights the conference's key topical issues.

\section{The Context of Private Higher Education Growth}

Most private institutions in Africa were established during the 1990s, in a relatively new higher education environment that is undergoing major developments. As in many developing countries, the demand for higher education beyond what public institutions provide is largely responsible for the growth. Additionally, some churchrelated private institutions provide alternatives to the general public institutions. And in some African countries private institutions have emerged due to deterioration (sometimes near collapse) of their public sectors, which are suffering from a severe lack of resources, funding shortfalls due to inflation and population increases (not commensurate to the successful primary and secondary education), as well as social disturbances such as wars, gangsterism, and cultism. Such a collapse, in turn, strains private institutions because they are regarded as safer zones of learning. South Africa is an exception to these trends as its leading public universities retain high quality and as profit making and "credentialism" largely drive its private higher education growth, a common feature in developed countries worldwide.

Proponents of private provision of higher education claim institutional and program diversity. Considering education as a "public good," however, many governments formulate policies that tightly regulate private institutions. In Ghana, for example, private university colleges must affiliate with public universities academically, but remain autonomous administratively. While this arrangement is said to aim at quality assurance of the affiliate institutions, the potential for isomorphism - the convergence of identities of different institutions-is high and might stifle the development of private institutions. An approach finding general approval in Kenya gives a commission for higher education overall responsibility for licensing private higher education institutions. In other African states, such as Zimbabwe, private institutions operate on par with their public counterparts. State policies, therefore, are central to the growth of private higher education institutions and affect them in different ways.

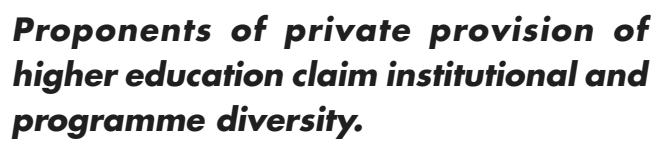

\section{Key Challenges}

Even when Africa's private institutions absorb excess demand (however incompletely in some countries), expand access, and provide institutional diversity, they still have to convince stakeholders that they can be relied upon to offer quality education. Inadequate facilities (including libraries and modern technology) and under-qualified personnel hamper their efforts. Moreover, most African higher education systems are losing quality academics through retirement, emigration to developed countries, and migration to private enterprise. Even more troubling is their inability to replenish such losses. Moreover, experienced academics are underutilized, especially with regard to nurturing young academics. The lack of staff development strategies ensures continued reliance on public institutions for trained staff. This is self-crippling to the sustainability of quality, a problem private institutions are acutely aware of because some of their personnel are retired professors from public institutions. Some critics, however, regard the employment of retired professors as an indictment of quality. There is no evidence, though, that this lowers standards, and actually the opposite is true. Such criticisms often stem from fear of change and competition on the part of mainstream institutions. Indeed, improvement of quality education and services can make private higher education institutions better alternatives to public institutions.

Whether or not many private institutions will attract top students, a pressing challenge is to 
exchange traditional curriculum development for new and innovative models. If they are to provide real program differentiation, private institutions need to determine social needs and develop curricula accordingly. Such curricula should then withstand the proof of quality maintenance and assurance while continuing to adapt to local needs and labor market demands. Broadly, private institutions in Africa seek to strive for international competitiveness with curricula that take cognizance of universal graduate standards. In the midst of these challenges, some institutions grapple with requirements of their owners, who often interfere with governance, recruitment of personnel, and academic progress.

A political problem for many private institutions, as previously experienced in Latin America and Eastern Europe, is their tendency to specialize in inexpensive fields of study that are in high demand. Natural and physical sciences, engineering, and technology remain largely peripheral, however much they are core to national development. Private higher education faces the challenge of offering diverse disciplines if it wants the status of universities of repute.

\section{A political problem for many private institutions is their tendency to special- ize in inexpensive fields of study that are in high demand.}

\section{Conclusion}

Many challenges facing Africa's private higher education institutions also confront its public institutions, though often in different ways and magnitudes. African private higher education primarily plays a supportive role to public-sector institutions. If this role is vital, then public policy issues arise over governments lending a supportive hand, trying to shape growth toward meaningful social development. Issues also arise over how both public and private institutions might together address challenges in their systems. Similarly, issues emerge over how best to pursue human resources development, with what mix of competition and cooperation between the two higher education sectors. To approach such matters intelligently, public higher education institutions, the citizenry, and governments need to take note of the patterns of development, achievements, and limitations of the region's private higher education institutions. Perhaps these and other issues will be fruitfully addressed in the next regionwide conference on private higher education that South Africa is preparing to host.

\section{Foreign Higher Education Activity in China \\ Richard Garrett}

Richard Garrett is deputy director, Observatory on Borderless Higher Education. Address: Observatory on Borderless Higher Education, 36 Gordon Square, London WC1H OPF, UK. E-mail: r.garrett@obhe.ac.uk.

C hina is perhaps the world's most complex, overhyped, and underanalyzed market for transnational higher education. The country's size, combined with China's transition from a command to a pseudomarket economy and potential as a superpower, has prompted many higher education institutions in the developed world to explore the possibilities for market entry. The recent accession of China to the World Trade Organization and the increasingly favorable official view taken of in-country activity by foreign education institutions (new regulations came into force in September 2003), suggest a genuine opening up of the market. This article is based on two reports recently published by the Observatory on Borderless Higher Education (www.obhe.ac.uk).

From the Chinese perspective, the major benefits of foreign involvement are capacity, status, and innovation. China is rapidly becoming the most significant source of students studying abroad (sending over 63,000 students to the United States alone in 2002). However, like some other major source countries such as Malaysia and Singapore, China may come to view foreign-sourced, in-country provision as more cost-effective, in terms of reducing travel costs and stemming brain drain.

\section{Regulation of Foreign Activity}

The third and most recent piece of legislation on transnational provision was released in March 2003 and offers clarification on the prior 1995 regulations. (Both the 1995 and 2003 regulations are available in English on the Ministry of Education website.) Major features include the stipulation that foreign institutions must partner with Chinese institutions; partnerships must not seek profit as their objective; no less than half the members of the governing body of the institution must be Chinese citizens and the post of president or the equivalent must be a Chinese citizen residing in China; the basic language of instruction should be Chinese; and tuition fees may not be raised without approval.

The sustained proscription of foreign education institutions making a profit in China is in contrast to the 2002 law on domestic private higher education, which permits a "reasonable return." It would appear that no Chinese private higher education institution has yet won approval to offer programs leading to foreign degrees, 